Corresponding Author: Rita Dwi Pratiwi; email:

ritadwipratiwi@wdh.ac.id

Published: 7 February 2022

Publishing services provided by Knowledge E

(c) Rita Dwi Pratiwi et al. This article is distributed under the terms of the Creative Commons Attribution License, which permits unrestricted use and redistribution provided that the original author and source are credited.

Selection and Peer-review under the responsibility of the IVCN Conference Committee.

\section{Psychosocial Development of Children Addicted Versus Not Addicted to Smartphones}

\author{
Rita Dwi Pratiwi ${ }^{1, *}$, Lukman Handoyo ${ }^{1}$, Siti Novy Romlah ${ }^{2}$ and Titi Rohaeti ${ }^{1}$ \\ 'Department of Nursing, Sekolah Tinggi IImu Kesehatan Widya Dharma Husada Tangerang, \\ Tangerang Selatan, Banten, Indonesia \\ ${ }^{2}$ Department of Midwifery, Sekolah Tinggi IImu Kesehatan Widya Dharma Husada Tangerang, \\ Tangerang Selatan, Banten, Indonesia
}

\section{ORCID}

Rita Dwi Pratiwi: https://orcid.org/0000-0001-7001-1221

\begin{abstract}
Psychosocial development of preschool children is the process of children's abilities developing and children starting to take the initiative to solve their own problems according to their knowledge. However, many preschool children are currently addicted to gadgets such as smartphones, which can interfere with their taking initiative and paying attention to the social environment. The aim of this study was to determine the differences in psychosocial development between children who are addicted vs. those who are not addicted to smartphones in preschool age children. This study was a descriptive comparative study and it used a simple random sampling technique to select the respondents. The Mann-Whitney test was employed to analyze the data with a significance degree of 0.05 (5\%). The results showed that there was a significant difference between addicted and non-addicted children. In the non-addicted group of children, the median value was 2.00 (1.61-1.78) and in the addicted group of children the median value obtained was 1.00 (1.03-1.11). The average ranking for the non-addicted group was 52.50 and was 28.50 for the addicted group. It is recommended that parents understand the impact of using gadgets such as smartphones on children's psychosocial development, and that parents pay more attention to each phase of children's development, especially psychosocial development at preschool age.
\end{abstract}

Keywords: gadget addiction, preschool children, psychosocial development

\section{Introduction}

In this modern era, technology development has been increasingly advanced and developing rapidly [1], including in Indonesia. Many advanced technologies have appeared that make great changes to human life [2]. One of the technologies that are currently developing is the development of increasingly widespread gadgets. Currently, gadget users are not only adults but also children and toddlers [3]. The study in Indonesia showed that that $63 \%$ of children spend a maximum of 30 minutes playing a game at a 
time, while $15 \%$ of parents state that children play games for 30 to 60 minutes, and the rest can interact with a game for more than one hour [4].

The impact that can occur on children due to long hours of playing a smartphone is a decrease in children's attention and participation in the social environment [5]. Children often playing with gadgets will ignore their social environment and prefer to play with their smartphones than hanging out with their friends [6]. This phenomenon can slowly change norms and behavior so that they are not aware of excessive gadget use and can cause them to suffer from gadget addiction.

The World Health Organization (WHO) reports that 5-25\% of preschool-aged children suffer from developmental disorders. Various child development problems, such as motor delays, language, and social behavior, have increased in recent years. Approximately $9.5 \%$ to $14.2 \%$ of preschool children have social-emotional problems that have a negative impact on their development and school readiness [7]. These developmental disorders are caused by many things, one of which is parents' lack of knowledge about parenting [8]. In this sophisticated era, it is possible that smartphones can also affect children's development. The purpose of this study was to determine the differences in psychosocial development between children who are addicted and who are not addicted to gadgets (smartphones).Method

This study was descriptive comparativeThis study was conducted on 27 May - 2 June 2021 in Darmakradenan Village, Ajibarang District, Central Java, Indonesia. The population in this study was 102 children aged 3-6 years old. The research samples are 80 respondents divided into two groups, namely the addicted group and the non-addicted group, with 40 respondents in each group. This study sampling used probability sampling with a simple random sampling technique.Results

Based on Table 1, The Age of Parents, in the non-addicted group, the most fathers were $20-30$ years old as many as 30 people (75.0\%), and almost half of the mothers were $30-40$ years old, namely 18 people (45.0\%). Based on the parents' education, almost half of the father's education was a Secondary School, as many as 17 people (42.5\%), and nearly half of the mother's education was a Secondary School, as many as 18 people (45.0\%). Based on the parents' occupation, the private employee fathers were 23 people (57.5\%), and the overall housewives were 40 people (100.0\%). Most of the parents' income was Rp. 1,500,000-Rp. 2,500,000, namely 21 people (52.5\%). Based on the age of children, almost half of them were 6 years old, as many as 13 children (32.5\%). Almost half of the parents had two children, namely 19 people (47.5\%). Based on the birth order of children in the family, most of the children were firstborns/ only child, as many as 21 people (52.5\%). Based on the frequency of gadget use, almost 
half of the children used gadgets seven days a week, as many as 19 children (47.5\%). Based on the duration of gadget use, most children used it 1-30 minutes a day, namely 21 children (52.5\%). All of the children lived with their parents, namely 40 people (100\%).

Meanwhile, in the addicted group, was nearly half of the fathers were more than $\mathbf{4 0}$ years old, namely 18 people (45,0\%), and most of the mothers' age was 30-40 years old, as many as 22 people (55,0\%). Based on the parents' education, most of the fathers' education was a Primary School, namely 30 people $(75,0 \%)$, and most of the mothers' education was a Secondary School, namely 29 people (42,5\%). Based on the parents' occupation, most of the fathers had others occupation, namely 27 people (67,5\%), and the overall housewives were 33 people (82,5\%). Half of the parents' income was Rp. 1.500.000-Rp. 2.500.000, as many as 20 people (50,0\%). Based on the age of children, nearly half of the children age was 6 years old, namely 14 children (35,0\%). Almost half of the parents had two children, namely 18 people $(45,5 \%)$. Based on the birth order of children in the family, most of the children were the firstborns/ only child, as many as 18 children (45,0\%). Based on the frequency of gadget use, almost all gadget-addicted (smartphone) children used it 7 days a week, namely 38 children (95,0\%). Based on the duration of gadget use, most of the children used it for 1-30 minutes a day, as many as 21 children (52,5\%). All of the children lived with their parents, as many as 40 children (100\%).

Based on Table 2, the psychosocial development of children, in the non-addicted group, most of the children were in the initiative stage, as many as 30 respondents (75.0\%), and the rest children were in the guilt stage, as many as 10 respondents (25.0\%). Meanwhile in the addicted group, almost all the children were in the guilt stage, namely 34 respondents $(85,0 \%)$, and the rest children were in the initiative stage, as many as 7 respondents $(15,0 \%)$.

According to Table 3, in the non-addicted group, all the children didn't suffer gadgetaddiction, as many as 40 respondents (100,0\%). Meanwhile According to table 2 , in the addicted group, half of the respondents suffered low level of gadget-addiction, as many as 20 respondents (50,0\%), almost half of them suffered medium level of gadgetaddiction, namely 17 respondents (42,5\%), and the rest, 3 respondents $(7,5 \%)$, suffered high level of gadget-addiction.

Table 4 shows that the non-addicted children, in the initiative stage, were 30 respondenta (37.5\%) and there were 10 (12.5\%) addicted children in the guilt stage. In the guilt stage, 15 children (18.8\%) suffered from gadget addiction with low levels and there were 5 children (6.3\%) in the initiative stage. In the guilt stage, 16 children $(20.0 \%)$ suffered from gadget addiction with medium levels and there was one child (1.3\%) in the initiative 
TABLE 1: Characteristics of respondents

\begin{tabular}{|c|c|}
\hline Characteristics & Non-addic \\
\hline & $f$ \\
\hline $\begin{array}{l}\text { Age of Fathers Ayah } 20-30 \text { years old } 30 \text { - } \\
40 \text { years old }>40 \text { years old }\end{array}$ & 5305 \\
\hline $\begin{array}{l}\text { Age of Mothers } 20-30 \text { years old } 30-40 \\
\text { years old }>40 \text { years old }\end{array}$ & 18175 \\
\hline $\begin{array}{l}\text { Occupation of Fathers Private Employ- } \\
\text { ees Civil Servants Indonesian Republic } \\
\text { Police/ Indonesian National Army Unem- } \\
\text { ployed Others }\end{array}$ & $\begin{array}{llll}23 & 0 & 0 & 0 \\
17 & \end{array}$ \\
\hline $\begin{array}{l}\text { Occupation of Mothers Private Employ- } \\
\text { ees Civil Servants Indonesian Republic } \\
\text { Police/ Indonesian National Army House- } \\
\text { wives Others }\end{array}$ & 00040 \\
\hline $\begin{array}{l}\text { Education of Fathers Primary School } \\
\text { Secondary School High School Colleges }\end{array}$ & 141772 \\
\hline $\begin{array}{l}\text { Education of Mothers Primary School } \\
\text { Secondary School High School Colleges }\end{array}$ & 161842 \\
\hline 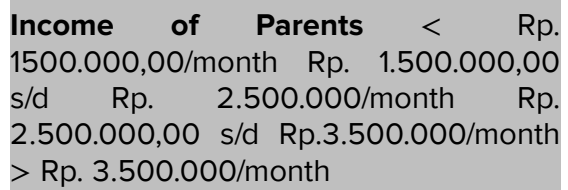 & 152140 \\
\hline
\end{tabular}

Age of Children 3 years old 4 years old 118813 5 years old 6 years old

Number of Children One/ only child Two 121981
Three Four or more

Birth Order of Children First born/ only 211351 child Second child Third child Fourth child or more

\section{Living with Parents Yes No}

Frequency of Gadget Use 1-3 days/ a 13819 week (low) 4-6 days/ a week (medium) 7 days/ a week (high)

Duration of Gadget Use 1-30 minutes/ a 21118 day 31-60 minutes/a day $>60$ minutes/a day

Amount

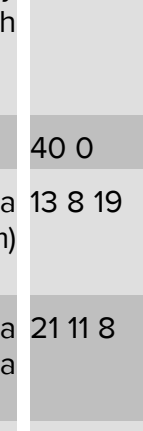

40

$\%$
12,5
75,0
12,5
45,0
42,5
12,5
57,5
$0 \quad 0 \quad 0$
42,5

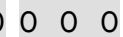

100,00

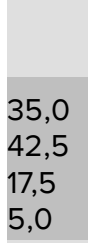

5,0

45,0

10,0

5,0

37,5

52,5

10,00

27,5

20,0

20,0

32,5

30,0

47,5

20,0

2,5

52,5

32,5

12,5

2,5

100,0 0

32,5

20,0

47,5

52,5

27,5

20,0

$100,0 \%$
Addicted $n(40)$

f $\%$

8141820,0

35,0

45,0

922922,5

55,0

22,5

1300032,500

$027 \quad 067,5$

$\begin{array}{llllll}0 & 0 & 0 & 0 & 0 & 0\end{array}$

$337 \quad 82,517,5$

309175,0

$\begin{array}{lll}0 & 22,5 & 2,5\end{array}$

0

299272,5

$0 \quad 22,5 \quad 5,0$

0

1620340,0

$1 \quad 50,0 \quad 7,5$

2,5

107925,0

$14 \quad 17,522,5$

35,0

$\begin{array}{llll}5 & 18 & 9 & 12,5\end{array}$

$8 \quad 45,0$

22,5

20,0

1018725,0

$5 \quad 45,0 \quad 17,5$

12,5

$400 \quad 100,00$

20385,0

95,0

51421

$12,535,0$

52,5

40

$100,0 \%$ 
TABLE 2: Psychosocial development of preschool children

\begin{tabular}{|c|c|c|c|c|c|}
\hline \multirow{2}{*}{\multicolumn{2}{|c|}{ Variable }} & \multicolumn{2}{|c|}{ Non-addicted $(n=40)$} & \multicolumn{2}{|c|}{ Addicted $(n=40)$} \\
\hline & & f & $\%$ & f & $\%$ \\
\hline $\begin{array}{l}\text { Psychosocial Development } \\
\text { Stage Initiative Stage }\end{array}$ & Guilt & 1030 & $25,075,0$ & $\begin{array}{l}34 \\
6\end{array}$ & $85,015,0$ \\
\hline Amount & & 40 & $100,0 \%$ & 40 & $100,0 \%$ \\
\hline
\end{tabular}

TABLE 3: Preschooler gadget addiction level

\begin{tabular}{|c|c|c|c|c|c|c|c|c|}
\hline & \multicolumn{2}{|c|}{ Non-addicted $(n=40)$} & \multicolumn{6}{|c|}{ Addicted $(n=40)$} \\
\hline & \multirow[b]{2}{*}{$f$} & \multirow[b]{2}{*}{$\%$} & \multicolumn{2}{|c|}{ Low } & \multicolumn{2}{|c|}{ Medium } & \multicolumn{2}{|r|}{ High } \\
\hline & & & $f$ & $\%$ & f & $\%$ & $f$ & $\%$ \\
\hline & 40 & 100,0 & 20 & 50,0 & 17 & 42,5 & 3 & 7,5 \\
\hline Amount & 40 & 100,0 & 20 & 50,0 & 17 & 42,5 & 3 & 7,5 \\
\hline
\end{tabular}

stage. There were 3 gadget-addicted children (3.8\%) with high levels in the guilt stage, and there was no gadget-addicted children in the initiative levels.

According to Table 5, the Mann-Whitney test results were $p$-value $=0,000$, value Asymp.Sig. (2-tailed) as much as 0,000, then statistically there was a significant difference. In the non-addicted group, it had a median value of $2,00(1,61-1,78)$, and in the addicted group, the median value was 1,00 (1,03-1,11). The average rank of the addicted group was 52,50 , and the addicted group was 28,50 .

\section{Discussion}

This study shows that there were differences in psychosocial development in children who are addicted to and not addicted to gadgets. Children who are not addicted to gadgets are indicated to have a higher initiative than children who are addicted to gadgets. The stages of psychosocial development that preschool children go through are passing through the dilemma between initiative or guilt [9]. Normally, preschoolers have to play a lot and interact with their peers and the wider social environment. When children socialize, a feeling of initiative will emerge [10]. However, if children spend more

TABLE 4: Comparative Study Cross Tabulation Analysis Results

Psychosocial
Development
Guilt stage
Initiative stage
Total

\begin{tabular}{l|l|} 
Non-addicted \\
\hline f & $\%$ \\
\hline 10 & 12,5 \\
\hline 30 & 37,5 \\
\hline $\mathbf{4 0}$ & $\mathbf{5 0 , 0}$ \\
\hline
\end{tabular}

\begin{tabular}{|c|c|c|c|c|c|c|c|}
\hline \multicolumn{8}{|c|}{ Addicted } \\
\hline \multicolumn{2}{|c|}{ low } & \multicolumn{2}{|c|}{ medium } & \multicolumn{2}{|c|}{ high } & \multicolumn{2}{|c|}{ Total } \\
\hline$f$ & $\%$ & $f$ & $\%$ & $f$ & $\%$ & $n$ & $\%$ \\
\hline 15 & 18,8 & 16 & 20,0 & 3 & 3,8 & 44 & 55,0 \\
\hline 5 & 6,3 & 1 & 1,3 & 0 & 0 & 36 & 45,0 \\
\hline 20 & 25,0 & 17 & 21,3 & 3 & 3,8 & 80 & 100,0 \\
\hline
\end{tabular}


TABLE 5: Mann-Whitney Analysis Test Results

\begin{tabular}{|c|c|c|c|}
\hline & & $\begin{array}{l}\text { Median (Minimum- } \\
\text { Maximum) }\end{array}$ & Value P-Value \\
\hline $\begin{array}{l}\text { Psychosocial } \\
\text { Development }\end{array}$ & $\begin{array}{l}\text { Non-addicted } \\
(n=40) \quad \text { Addicted } \\
(n=40)\end{array}$ & $\begin{array}{l}2,00(1,61-1,78) \quad 1,00 \\
(1,03-1,11)\end{array}$ & $0,000-0,000$ \\
\hline
\end{tabular}

time playing smartphones, then the opportunity to develop a sense of initiative will not be optimal. It could even be, they may not even know how to feel guilty about doing or not doing something. The results of this study are in line with a study conducted by Keumala [11], which showed that children who often play gadgets can experience attention disorders. If the child has a disturbance in attention, then the child may be insensitive to the social environment and have a low sense of initiative.

The results of this study also indicate that children who are addicted to gadgets are affected by the low educational background of their parents. The level of parents' education greatly influences how parents attempt to provide parenting. Parents with higher levels of education have better literacy skills so that they are more exposed and easily absorb information about appropriate parenting [12]. With the high level of parents' education and the application of appropriate parenting patterns, children will more easily get any achievements [13,14]. In contrast to parents with lower education levels, they more often apply parenting according to their experiences (a reflection of the treatment they have received) [15]. Parents with low levels of education may tend to want an easy way by giving children gadgets so their children don't cry and sulk. Even so, parents with lower levels of education are not absolutely certain to have children who are addicted to gadgets, as long as the family applies the values of discipline.

The number of children in the family is a contributing factor to the incidence of gadget addiction in children. The results of this study illustrate that most children who are addicted to gadgets have many siblings (the number of children is more than two). This can be due to the fact that the focus of parents in parenting is divided for many children. Two different studies conducted by Naikang and Black explains that the more the number of siblings in the family, the more it can affect the quality of children's education $[16,17]$. This indicates that the number of children in the family greatly affects the success of parenting for their children. The higher the number of children, the more complex the problems in children. Unlike the case with parents who have only one or two children, they can focus more on educating and assisting children so that the risk of addiction to gadgets can be reduced. 


\section{Conclusion}

This study indicated that there is a difference of psychosocial development between gadget addicted and non-gadget-addicted children in Darmakradenan Village, Ajibarang District, Central Java, Indonesia. Parents who have preschool age children in the technological development era like today are strongly encouraged to pay attention to their children's screen time so they don't get addicted to gadgets. Adequate communication needs to be improved between parents and children. Family nurses need to collaborate with pediatric nurses to plan interventions for parents to be able to provide optimal parenting for children who are very much related to gadgets.

\section{Conflict of Interest}

The authors have no conflict of interest to declare.

\section{References}

[1] Li B, Piachaud D. Technological innovations and social development in Asia. Journal Asian Public Policy. 2019;12(1). Doi: 10.1080/17516234.2018.1546419

[2] Ra S, Shrestha U, Khatiwada S, Yoon SW, Kwon K. The rise of technology and impact on skills. International Journal of Training Research. 2019;17(Sup. 1):26-40. Doi: $10.1080 / 14480220.2019 .1629727$

[3] Radesky JS, Weeks HM, Ball R, et al. Young children's use of smartphones and tablets. Pediatrics. 2020;146(1). Doi:10.1542/peds.2019-3518

[4] Delima R, Arianti NK, Pramudyawardani B. Identifikasi kebutuhan pengguna untuk aplikasi permainan edukasi bagi anak usia 4 sampai 6 tahun. Jurnal Teknologi Informasi dan Sistem Informasi. 2015;1(1).

[5] Ihm J. Social implications of children's smartphone addiction: The role of support networks and social engagement. Journal of behavioral addictions. 2018;7(2):47381. Doi: $10.1556 / 2006.7 .2018 .48$

[6] Suhana M. Influence of gadget usage on children's social-emotional development. In International Conference of Early Childhood Education (ICECE 2017). 2017;169. Doi: 10.2991/icece-17.2018.58

[7] Brauner CB, Stephens CB. Estimating the prevalence of early childhood serious emotional/behavioral disorders: Challenges and recommendations. Public health reports. 2006;121(3):303-10. Doi: 10.1177/003335490612100314 
[8] Aldayel AS, Aldayel AA, Almutairi AM, Alhussain HA, Alwehaibi SA, Almutairi TA. Parental knowledge of children's developmental milestones in Riyadh, Saudi Arabia. International Journal Pediatrics. 2020. Doi: 10.1155/2020/8889912

[9] Orenstein GA, Lewis L. Eriksons stages of psychosocial development. StatPearls [Internet]; 2020.

[10] Korotaeva EV, Svyattseva AV. Initiative development in preschool children. ProcediaSocial and Behavioral Sciences. 2016;233:280-6. Doi: 10.1016/j.sbspro.2016.10.127

[11] Keumala M, Yoestara M, Putri Z. The Impacts of gadget and internet on the implementation of character education on early childhood. Paper presented at: The International Conference on the Roles of Parents in Shaping Children's Characters; 2018; Banda Aceh, Indonesia.

[12] Kiadarbandsari A, Madon Z, Hamsan HH, Nouri KM. Role of parenting style and parents' education in positive youth development of adolescents. Pertanika Journal of Social Sciences \& Humanities. 2016;24(4).

[13] Davis-Kean PE. The influence of parent education and family income on child achievement: The indirect role of parental expectations and the home environment. Merrill-Palmer Quarterly (1982-). 2005;19(2):294-304. Doi: 10.1037/08933200.19.2.294

[14] Schlechter M, Milevsky A. Parental level of education: Associations with psychological well?being, academic achievement and reasons for pursuing higher education in adolescence Educational Psychology. 2010;30(1). Doi: 10.1080/01443410903326084

[15] Haderlie K. The impact of parents' past experiences on parenting styles and practices in organized youth sport. Paper presented at: Utah Conference on Undergraduate Research; 2014; Utah State University; United States.

[16] Feng N. The effect of sibling size on children's educational attainment: Evidence from Indonesia. ECNU Review of Education. 2020. Doi: 10.1177/2096531120921703

[17] Black S, Devereux P, Salvanes K. The more the merrier? The effect of family size and birth order on children's education. London School of Economics; 2005. 